TAPROBANICA, ISSN 1800-427X. October, 2012. Vol. 04, No. 02: pp. 83-87.

(C) Taprobanica Private Limited, 146, Kendalanda, Homagama, Sri Lanka.

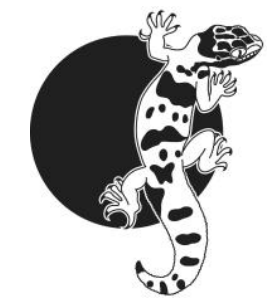

\title{
GROUP-SIZE AND AGE-SEX COMPOSITION OF NILGIRI LANGUR Trachypithecus johnii (PRIMATES: CERCOPITHECIDAE) IN INDIA
}

Debahutee Roy

Department of Zoology, Division of Wildlife Biology, A.V.C. College Mannampandal, Mayiladuthurai, Tamil Nadu, India; Email: moni.roy8@gmail.com

\begin{abstract}
Group size and group composition of Nilgiri langur (Trachypithecus johnii) was studied in two habitats of Parambikulam Tiger Reserve, Kerala, India. Group size and age-sex composition data was collected during scan sampling, 18 monitoring transect lines, road-strip count, and direct encounter of the groups. Mean group size value significantly differ between moist deciduous forest and evergreen forest. Group size was varied from 2 to 22. The maximum group size, 22 was recorded in evergreen forest habitat. The mean group size of Nilgiri langur is less in moist deciduous forest and higher in evergreen forest.
\end{abstract}

Key words: Demographic parameters, colobines, Parambikulam Tiger Reserve, Western Ghats

\section{Introduction}

Primates are typically group living, and Asian colobines are typically organized into one-male social group (Yeager, 2000). Group size is influenced by environmental conditions such as season, habitat openness, and food availability (Leuthold \& Leuthold, 1975; Southwell, 1984). Many estimates of group size and composition are derived from sampling transects (Jathanna et al., 2003; Karanth \& Sunquist, 1992; Varman \& Sukumar, 1995); however, such estimates often underestimates the actual values (Burnham et al., 1980).

Nilgiri langurs are endemic to parts of Kerala, India and are reported to live in larger groups of approximately 15 animals (Poirier, 1968).The group size has been varyingly reported to range between 2 to 29 . It has been found to be smaller (6-8 animals) in deciduous forest than in evergreen forest (18-20 animals) (Malviya, 2011). Further, Nilgiri langur have been studied in the Western Ghats (Horwich, 1980; Poirier, 1968; Sunderraj, 2001), but not in the Parambikulam Tiger Reserve, Kerala, India. Nilgiri langur, is an endangered species and is endemic to the rainforests of the Western Ghats of India and is listed under Appendix II of CITES. They are also protected under the Schedule I, Part I of Indian Wildlife Protection Act, 1972 and are listed as Vulnerable C2A (i) 
under IUCN Red data list (Malviya, 2011).

\section{Materials and Methods}

Study area: Western Ghats extends from the southern Gujarat from Surat-Dangs to the end of Kaniyakumari in Tamil Nadu. The study area, Parambikulam Tiger Reserve $\left(647 \mathrm{~km}^{2}\right)$ is a part of Western Ghats, located in Palakad District of Kerala $\left(10^{\circ} 20^{\prime}-10^{\circ} 26^{\prime} \mathrm{N}, 76^{\circ} 35^{\prime}-\right.$ $\left.76^{\circ} 50^{\prime} \mathrm{E}\right)$. The reserve lies in between the Anamalai hills and Nelliampathy hills. The boundaries of the reserve are Nemmara Forest Division in North, Vazhachal Forest Division in South, Tamil Nadu in the East and Chalakudy in the West. The evergreen and moist deciduous forests are the most important natural vegetation types. The evergreen tropical forests are confined to small areas in the hilltops of Karimala Gopuram and in the foothills of Pandaravara peak which is known by the name Karian Shola (Anon, 2012). The sanctuary has very rich and diverse wildlife due to the mosaic pattern of vegetation.

Data collection: The study area was surveyed every month on foot from December 2011 to March 2012. Data on group size and composition were collected during monitoring of line transect, during the scan sampling, and from the groups which were encountered outside of these situations. In each habitat eighteen line transects each $1 \mathrm{~km}$ in length and placed in stratified random fashion. The line transects were monitored each day alternating between the two habitats. Individuals in a group were classified into different age and sex classes based on the criteria of (Sunderraj, 2001) with some modifications.

The group was classified into following categories: solitary males, all-male groups, and one-male multi-female groups. Solitary adult males and all male groups were not included in the age-sex composition. The chances of resighting of groups were possible. Hence the data collection was restricted in selected transects and roads once in a week. Furthermore counts in adjoining transects were avoided in the subsequent days to prevent double count and pseudoreplication. Langurs move approximately $900 \mathrm{~m}$ to $2 \mathrm{~km}$ per day depending on season (Poirier, 1968) and the distance between transects was only $100 \mathrm{~m}$. In addition if two groups had same size then the independence of these two data sets was checked using group composition and marking of the individuals of the groups.

The density and relative abundance of food plant species, species diversity, and richness in the two habitats were estimated by belt transects (eight in moist deciduous forest and ten in evergreen forest) within the Nilgiri langur ranging area to find out which of the two habitats appears to be more suitable for group formation of this species. In each habitat, $1 \mathrm{~km}$ transect was laid where a sub transect of $50 \times 2 \mathrm{~m}$ dimension was prepared, separated by at least $100 \mathrm{~m}$ (distance between adjacent transects) for vegetation analysis, based on the distance moved by the langurs. In each transects the variables such as tree species, GBH of the tree and vegetative phenology was recorded.

\section{Results}

A total of 18 groups were sighted and their size varied from 2 to 22 . The group size class and frequency of sighting is shown in the Figure 1. Other than solitary males which were recorded most frequently, the group size of five was most common in moist deciduous forest and the maximum group size, 22 in evergreen forest. The solitary individual sightings constituted $18 \%$ of overall sightings and they were all adult males. All male groups of 17 individuals were sighted once in the moist deciduous forest.

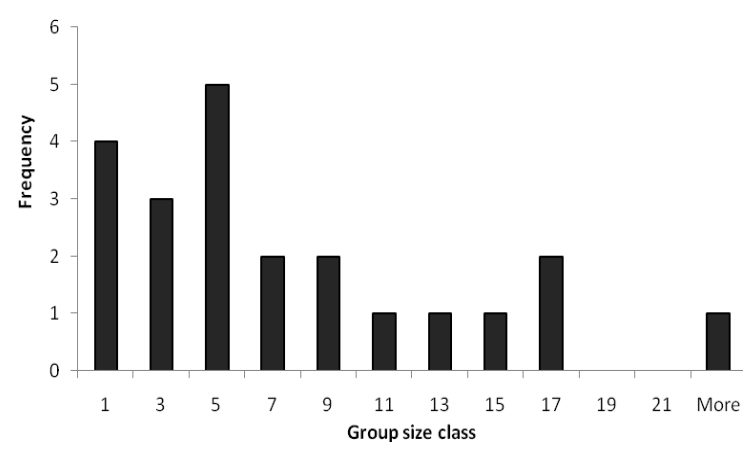

Figure 1: Frequency distribution of group size classes of Nilgiri langur at PTR.

The mean group size of Nilgiri langur was $(7.72 \pm 5.54)$. The mean group size in evergreen and moist deciduous forest was $11.78 \pm 5.09$ and $3.67 \pm 1.50$ respectively. Thus the mean group size of Nilgiri langur was significantly higher in evergreen forest $(\mathrm{F}=14.93 ; \mathrm{p}<0.001$ (Fig. 2).

An all-male group was also sighted once during the study. A multi sex group is composed of one adult male, few adult females with or 
without infants, sub-adults and juveniles (Fig. 3). Adult female constituted the highest percent of the group size $50 \pm 2.94 \%$ and $40.6 \pm 11.59 \%$ in both moist deciduous and evergreen forests respectively. The percent composition of adult male was higher in moist deciduous forest (29\%) than evergreen forests $(13.04 \%)$. The percent composition of sub-adult male, subadult female and juvenile was higher in evergreen forests $(11.59 \%, 26 \%$ and $8.7 \%$ ) respectively. Thus the percent composition of different age-sex classes of Nilgiri langur varied significantly in association with the habitat types $\left(\chi^{2}=28.95 ; \mathrm{df}=6 ; \mathrm{p}<0.05\right)$.

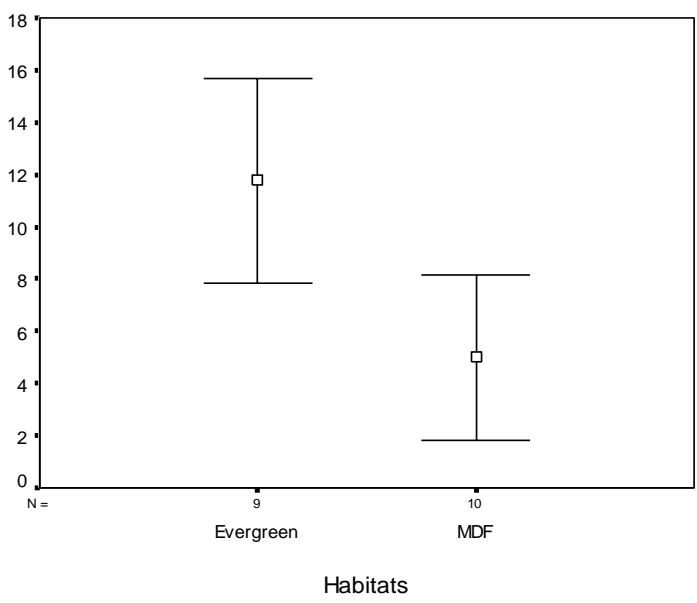

Figure 2: Mean group size of Nilgiri langur in two habitats at PTR $(\mathrm{F}=14.93 ; \mathrm{p}<0.001)$.

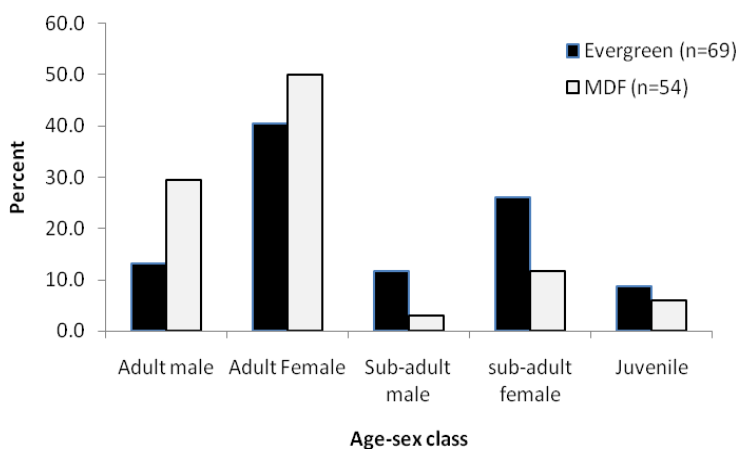

Figure 3: Age sex composition of Nilgiri langur in different habitats at PTR $\left(\chi^{2}=28.95 ; \mathrm{df}=6 ; \mathrm{p}<0.05\right)$.

In the two habitats, tree species richness and diversity were higher in the evergreen forest (144 sp., $\mathrm{H}=2.8 \pm 0.4$ ) than in moist deciduous forest (86 sp., $\mathrm{H}=2.4 \pm 0.3$ ). Mean tree height and mean $\mathrm{GBH}$ were higher in moist deciduous forest $(43.8 \pm 7.7 \mathrm{~m}, \quad 35.8 \pm 12.4 \mathrm{~cm})$ than in evergreen forest $(36.1 \pm 5.9 \mathrm{~m}, 30.5 \pm 9.1 \mathrm{~cm})$. In tree vegetative phenology the percent young leaves was significantly more in the evergreen forest $(11.8 \% \pm 4.39)$ than in moist deciduous forest $(8.3 \% \pm 6.05)$. Percentage of mature leaves was more in moist deciduous forest $(91.7 \% \pm 6.05)$ than in the evergreen forest $(88.2 \% \pm 4.39)$.

\section{Discussion}

The most basic characteristics of primate societies have traditionally been based on social organization alone. Asian colobines are typically organized into one-male social group (Yeager, 2000). Nilgiri langurs living in parts of Kerala appear to live in larger groups of approximately 15 animals with a higher adult male- adult female ratio than typically reported for most langurs (Poirier, 1968). The group size has been varyingly reported to range between 2 to 29. It has been found to be smaller (6-8 animals) in deciduous forest as compared to evergreen (18-20 animals) (Malviya, 2011).

Group formation and sizes can be influenced by foraging behavior (Jarman, 1974). The number of groups and their size are mainly determined by food resource availability and competition between males which leads to the splitting up of groups (Narasimmarajan et al., 2011). The mean group size of Nilgiri langur varied significantly among the two different habitats. The mean group size of Nilgiri langur was less in moist deciduous forest than the evergreen forest, possibly because more open habitat could not allow the formation of larger groups (Barrette, 1991). The standard ecological model assumes that better predation avoidance as group size increases favours living in larger groups, whereas increased travel costs and reduced net food intake due to within-group competition for resources set the upper limit (Steenbeek et al., 2001). There are two main competing theories on the evolution of group living in diurnal nonhuman primates. The first theory claims that predation avoidance favours group living, whereas there are only disadvantages to feeding in a group and feeding competition increases with group size (van Schaik, 1983). The second theory claims that there is a feeding advantage to group living deriving from communal defense of highquality food patches and that predation is not important (van Schaik, 1983). These theories have not yet been rigorously tested. Though food resources might limit the maximum group size, predation pressure influences the 
formation of groups (Jarman, 1974). Benefits of group living for primates fall into three board categories: predator avoidance, foraging advantages, and avoidance of conspecific threat (Gillespie et al., 2001). The predation avoidance hypothesis claims that primates live in groups to reduce the risk of predation, despite the increased cost of within group feeding competition (Treves et. al., 1996).

Earlier study by Sunderraj (2001), reported a mean group size of 5-18 in Western Ghats. He stated the variation in group size of Nilgiri langur may be influenced by the availability of food, temperature, and human disturbance. Here in the current study the mean group size of Nilgiri langur was less in moist deciduous than evergreen forest. Barrette (1991) emphasized that open habitat did not allow the formation of larger groups as the distribution of food resource may not be uniform in open habitat. An increase in group size normally increases the distance that must be travelled to find adequate food supplies (Chapman et al., 2000) where they expend more energy to forage if they are in a large group and where the distribution of food is not consistent. Primates adjust their intensity of use for foraging area and their daily movements according to food availability (Tsuji et al., 2009).

Tree species composition in Nilgiri langur habitats were compared and analyzed where the diversity and percent of young leaves is more in the evergreen forest. Consumption of leaves satisfied the nutrient requirement. Young leaves are reported to contain high percentage of crude protein and contains less fiber. Availability of young leaves contributes to whether or not a particular species is chosen for food (Solanki et al., 2008). Regarding group size variation, my observation and analysis showed that Group size in Nilgiri langur varies with habitat type with respect to food availability as the main reason next to predation risk as in the current study the result of vegetation analysis has shown that the abundance of food plants with respect to richness and diversity is more in evergreen forest and also this habitat type is supporting the larger group size. The study is only a preliminary investigation on the variation of group size in two different habitats. Thus group size may increase or decrease with food availability, food species diversity and richness.

\section{Acknowledgements}

I thank Michael Wasserman (McGill University, Canada) for reviewing the manuscript, S. Sandilyan for guidance and the Kerala Forest Department, India for permission to conduct research within Parambikulam Tiger Reserve. I thank M. Ashokkumar and D. Boominathan (senior project officers, WWF) for their help in statistical analysis and the WWF for funding the study. I am grateful to K. Thiyagesan, principal of A.V.C College and J. Pandian, G. Sharmila, R. Nagarajan, S. Shankari and M. Kartikiyan of A.V.C College, Department of Zoology and Wildlife Biology for their support. I would like to thank Ajay Desai, co-chairman Asian Elephant Specialist Group IUCN for designing the study.

\section{Literature cited}

Altmann, J. 1974. Observational study of behavior: sampling methods, Behavior, 49:227267.

Anon, 2012. Parambikulam Tiger Reserve, downloaded from http:// www.parambikulam.org/ on 6 July 2012.

Barrette, C., 1991. The size of Axis deer fluid groups in Wilpattu National Park, Sri Lanka. Journal of. Mammalia, 55: 207-220.

Burnham, K. P., D. R. Anderson and J. L. Laake, 1980. Estimation of density from line transects sampling of biological populations, Wildlife. Monographs, 72: 1-202.

Chapman, C. A. and L. J. Chapman, 2000. Constrains on group size in red tailed guenons: Examining the generality of the ecological constrains model. International Journal of Primatology, 21 (4): 564-585.

Gillespie, T. R. and C. A. Chapman, 2001. Determinants of Group size in the Red Colobus monkey (Procolobus badius): an evaluation of the generality of the ecological constraints model. Behavioural ecology, 50 (4): 329-338.

Horwich, R.H., 1980. Behavioural rhythms in the Nilgiri langur, Presbytis johnii. Primates, 21 (2): 220-229.

Jarman, P. J., 1974. The social organization of antelope in relation to their ecology. Behaviour, 48: 215-220. 
Jathanna, D., K. U. Karanth and A. J. T. Johnsingh, 2003. Estimation of large herbivore densities in the tropical forest of southern India using distance sampling, Journal of Zoology., 261: 285-290.

Karanth, K. U. and M. E. Sunquist, 1992. Population structure, density and biomass of larger herbivores in the tropical forests of Nagarahole, India. Journal of Tropical Ecology, 8: 21-35.

Leuthold, W. and B. M. Leuthold, 1975. Pattern of social grouping in ungulates of Tsavo National Park, Kenya. Journal of Zoology., 175: 405-420.

Malviya, M., A. Srivastava, P. Nigam and P. C. Tyagi, 2011. National Study book of Nilgiri langur (Trachypithecus johnii). Wildlife Institute of India: 1-17

Narasimmarajan, K., R. Nagarajan and A. Kumaraguru, 2011. Some Observations on demography and edible plants of Lion-tailed Macaques (Macaca silenus) in the rain forest fragmented habitats of Anamalai Hills, Western Ghats. Journal of Research Biology: 1 (5): 352362

Poirier, F. E., 1968. Analysis of Nilgiri langur (Presbytis johnii) Home range change. Primates, 9: 29-43.

Poirier, F. E., 1970. Dominance structure of the Nilgiri langur (Presbytis johnii) of South India. Folia Primatologica, 12:161-186.

Schaik, C.V.P. 1983. Why are Diurnal Primates living in Groups? Behaviour, 87 (1\&2): 120-144.

Solanki G.S., Kumar, A. and Sharma B.K. 2008 b. Winter food selection and diet composition of capped langur (Trachypithecus pileatus) in Arunachal Pradesh, India Tropical Ecology, 49 (2):157-166.

Southwell, C. J., 1984. Variability in grouping in the eastern grey kangaroo, Macropus giganteus. Group density and group size. Australian Wildlife Research, 11: 423-435.

Steenbeek, R and Schaik, C.V.P. 2001. Competition and Group size in Thomas's langurs (Presbytis thomasi): the folivore Paradox revisited. Behavioural ecology and Sociobiology, 49. 2-3
Sunderraj, S. F. W., 2001. Ecology and conservation of Nilgiri langur (Trachypithecus johnii). Envis Bulletin: Wildlife and Protected Areas, 1 (1): 49-59.

Treves, A. and C. A. Chapman, 1996. Conspecific threat, predation avoidance and resource defense: implications for grouping in langurs. Behavioural Ecological Sociobiology, 39: $43-53$

Tsuji, Y. and S. Takatsuku, 2009. Effects of yearly change in net feeding on autumn homerange use by Macaca fuscata on Kinkazan Island, Northern Japan. International Journal of Primatology, 30: 169-181.

Yeager, C. P. and K. Kool, 2000. The behavioural ecology of Asian colobines. In: Old world monkeys, Whitehead, P. F. and C. J. Jolly (eds.). Cambridge University Press, Newark: 496-521. 